\title{
PEMANFAATAN TANAMAN OBAT (BIOFARMAKA) SEBAGAI PRODUK UNGGULAN MASYARAKAT DESA DEPOK BANJARNEGARA
}

\author{
Sarno \\ Program Studi Agroteknologi. Politeknik Banjarnegara \\ Jl. Raya Madukara KM 02, Kenteng Banjarnegara 53482 \\ Email: abisarno1@gmail.com
}

\begin{abstract}
Abstrak
Tanaman obat atau dikenal biofarmaka merupakan tanaman yang memiliki khasiat atau kegunaan sebagai tanaman obat terutama bagi keluarga masyarakat Desa Depok Kecamatan Bawang Kabupaten Banjarnegara. Tujuan kegiatan pengabdian kepada masyarakat yang dilakukan adalah membantu meningkatkan pengetahuan dan keterampilan masyarakat tentang pentingnya pemanfaatan tanaman biofarmaka sebagai obat yang berguna bagi kesehatan. Kegiatan dilaksanakan di Desa Depok dengan sasaran utamanya adalah masyarakat yang tergabung dalam kelompok wanita tani Sida Jodho. Bentuk dan metode kegiatan yang dilakukan adalah kegiatan pendidikan masyarakat melalui penyuluhan, ceramah, dan diskusi langsung tentang pemanfaatan biofarmaka. Selain itu juga dilakukan kegiatan difusi ipteks melalui kegiatan pelatihan pemanfaatan tanaman biofarmaka dan kegiatan advokasi melalui pendampingan secara berkelanjutan. Pelaksanaan kegiatan mulai dari tahapan persiapan, pelaksanaan, dan evaluasi kegiatan. Hasil kegiatan setelah pengabdian kepada masyarakat, menunjukkan bahwa pengetahuan dan keterampilan masyarakat tentang pemanfaatan tanaman biofarmaka sebagai produk unggulan meningkat daripada kondisi sebelum kegiatan.
\end{abstract}

Kata Kunci: Biofarmaka, Produk unggulan, Masyarakat, Desa, Banjarnegara

\section{PENDAHULUAN}

Tanaman obat atau dikenal dengan nama biofarmaka adalah jenis-jenis tanaman yang memiliki fungsi dan berkhasiat sebagai obat dan dipergunakan untuk penyembuhan atau pun mencegah berbagai penyakit. Berkhasiat obat sendiri mempunyai arti mengandung zat aktif yang bisa mengobati penyakit tertentu atau jika tidak memiliki kandungan zat aktif tertentu tapi memiliki kandungan efek resultan/sinergi dari berbagai zat yang mempunyai efek mengobati. Penggunaan tanaman obat sebagai obat bisa dengan cara diminum, ditempel, dihirup sehingga kegunaannya dapat memenuhi konsep kerja reseptor sel dalam menerima senyawa kimia atau rangsangan tanaman obat (biofarmaka) yang dapat digunakan sebagai obat, baik yang sengaja ditanam maupun tumbuh secara liar. Tumbuhan tersebut digunakan oleh masyarakat untuk diracik dan disajikan sebagai obat guna penyembuhan penyakit. Tumbuhan obat merupakan salah satu ramuan paling utama produk-produk obat herbal. Tanaman obat adalah bahan yang berasal dari tanaman yang masih sederhana, murni, belum diolah. Tanaman obat adalah tanaman atau bagian tumbuhan yang digunakan menjadi bahan obat tradisional atau obat herbal, bagian tanaman yang dipakai untuk bahan pemula bahan baku obat. Tanaman atau bagian tanaman yang diekstraksi dan ekstrak tumbuhan tersebut dipakai sebagai obat. Tanaman obat adalah obat tradisional yang terdiri dari tanaman-tanaman yang mempunyai khasiat untuk obat atau dipercaya mempunyai khasiat sebagai obat. Di mana khasiatnya diketahui dari hasil penelitian dan pemakaian oleh masyarakat (Anonim, 2012).

Seperti halnya Lestaridewi, dkk (2017) menyatakan bahwa Indonesia sebagai negara yang memiliki pelayanan kesehatan modern telah berkembang namun jumlah masyarakat yang memanfaatkan pengobatan tradisional tetap tinggi. Pemanfaatan tanaman sebagai obat (biofarmaka) masih dilakukan oleh masyarakat di Kabupaten Banjarnegara, salah satunya di Kecamatan Bawang atau tepatnya di Desa Depok. Sejak dahulu masyarakatnya telah banyak memanfaatkan tanaman sebagai bahan pengobatan untuk segala macam penyakit. Masyarakat yang ada di wilayah tersebut memiliki kekayaan pengetahuan tradisional dalam bidang pengobatan tradisional khususnya yang berkaitan dengan penyembuhan penyakit. Penduduk di Desa Depok ini kebanyakan masih memiliki pekarangan yang cukup luas dan bisa dimanfaatkan untuk menanam 
berbagai jenis tanaman obat serta tidak menutup kemungkinan banyak tanaman obat yang tumbuh liar di lahan tersebut. Secara turun temurun masyarakat khususnya yang mempunyai pekarangan baik sempitmaupun luas memanfaatkan pekarangannya untuk ditanami berbagai macam tanaman yang dapat dikonsumsi maupun digunakan sebagai sumber tanaman obat keluarga (toga).

Salah satu fungsi toga adalah sebagai sarana untuk mendekatkan tanaman obat kepada upaya-upaya kesehatan masyarakat yang antara lain meliputi upaya preventif (pencegahan), upaya promotif (meniungkatkan derajat kesehatan), dan upaya kuratif (penyembuhan penyakit). Selain fungsi diatas ada juga fungsi lainnya yaitu; (a) sarana untuk memperbaiki status gizi masyarakat, sebab banyak tanaman obat yang dikenal sebagai tanaman penghasil buah-buahan atau sayursayuran misalnya lobak, saledri, pepaya dan lain-lain, (b) sarana untuk pelestarian alam. Apabila pembuatan tanaman obat alam tidak diikuti dengan upaya-upaya pembudidayaannya kembali, maka sumber bahan obat alam itu terutama tumbuh tumbuhan akan mengalami kepunahan, (c) sarana penyebaran gerakan penghijauan. Untuk menghijaukan bukit-bukit yang saat ini mengalami penggundulan, dapat dianjurkan penyebarluasan penanaman tanaman obat yang berbentuk pohonpahon misalnya pohon asam, pohon kedaung, pohon trengguli dan lain-lain, (d) sarana untuk pemertaan pendapatan. Toga disamping berfungsi sebagai sarana untuk menyediakan bahan obat bagi keluarga dapat pula berfungsi sebagai sumber pengbasilan bagi keluarga tersebut, (e) sarana keindahan. Dengan adanya Toga dan bila di tata dengan baik maka hal ini akan menghasilkan keindahan bagi orang/masyarakat yang ada di sekitarnya. Untuk menghasilkan keindahan diperlukan perawatan terhadap tanaman yang di tanam terutama yang ditanam di pekarangan rumah (Tukiman, 2014).

Berlatar belakang dari pentingnya pemanfaatan tanaman obat (biofarmaka) bagi kesehatan masyarakat, maka keberadaannya harus diperhatikan dan ditingkatkan untuk mendukung peningkatan kesejahteraan dan pendapatan masyarakat. Dalam hal ini terutama masyarakat Desa Depok Kecamatan Bawang Kabupaten Banjarnegara. Desa Depok merupakan salah satu desa yang ada di Kecamatan Bawang yang memiliki luas wilayah mencapai 172,556 hektar atau sekitar 3,126 $\%$ dari luas keseluruhan Kecamatan Bawang 5.520,637 hektar. Memiliki 9 RT dan 2 RW serta jumlah penduduknya 1.069 jiwa. Desa dengan mayoritas penduduknya petani ini memiliki jarak tempuh 12 kilometer dari pusat kota Banjarnegara (Kecamatan Bawang Dalam Angka, 2018).

Desa Depok merupakan salah satu desa yang masih menyimpan banyak masalah didalam pengembangan dan pengolahan tanaman biofarmaka yang sebenarnya potensial akan tetapi belum digarap secara intensif. Pemanfaatan lahan di Desa Depok untuk pekarangan dan bangunan 17,553 Ha, dan tegalan atau kebun 114,338 Ha. Tanaman biofarmaka utama yang dikembangkan di Desa Depok meliputi jenis kencur, kapulaga, jahe, kunyit, lengkuas, sereh dan mrica. Hampir semuanya tanaman tersebut dikembangkan di lahan tegalan tumpangsari dengan tanaman pangan seperti jagung, kacang tanah dan singkong. Semua hasil panen biofarmaka yang dihasilkan dijual langsung ke konsumen atau ke pedagang pengepul dari luar desa. Artinya peluang untuk melakukan kegiatan pascapanen dan diversifikasi produk olahan biofarmaka menjadi produk yang berkhasiat obat memang belum dilakukan oleh masyarakat.

Desa Depok memiliki jumlah kelompok wanita tani sebanyak 1 kelompok, yaitu Kelompok Wanita Tani Sida Jodho yang berdiri sejak Desember 2015. Kelompok Wanita Tani Sida Jodho tersebut selama ini melakukan kegiatan produksi atau budidaya biofarmaka seperti kencur, kunyit, kapulaga, jahe, lengkuas, sereh dan mrica secara turun temurun. Atau dapat dikatakan bahwa kelompok semuanya mengusahakan atau mengembangkan budidaya biofarmaka dengan memanfaatkan lahan kering atau tegalan. Munculnya semangat dan motivasi warga masyarakat yang tergabung dalam kelompok wanita tani tersebut sejak awal dan sampai sekarang terus berkembang pesat meskipun terdapat berbagai kendala seperti harga pasaran biofarmaka yang rendah dan aksesnya masih tertutup, dan belum lagi ditambah keterampilan serta pengetahuan para kelompok yang masih terbatas terkait dengan pemanfaatan biofarmaka sebagai produk unggulan, penanganan pascapanen dan teknik pengolahan biofarmaka menjadi produk yang memiliki nilai tambah.

Kegiatan pemanfaatan tanaman biofarmaka belum banyak dilakukan oleh masyarakat Desa Depok terkhusus para anggota kelompok wanita tani. Hal tersebut disebabkan terbatasnya pengetahuan dan kemampuan para anggota kelompok wanita tani tentang pemanfaatan tanaman biofarmaka terutama sebagai produk unggulan berbasis potensi desa. Produk unggulan adalah 
produk yang memiliki nilai jual dan daya saing tinggi, serta daya tawar tinggi serta berbeda dengan produk lainnya. Sebagai produk unggulan tanaman biofarmaka secara tidak langsung akan berdampak pada upaya peningkatan kesejahteraan dan pendapatan masyarakat. Oleh karena itu tujuan kegiatan pengabdian kepada masyarakat tersebut adalah membantu meningkatkan pengetahuan dan keterampilan masyarakat tentang pentingnya pemanfaatan tanaman biofarmaka sebagai obat yang berguna bagi kesehatan.

\section{METODE}

Sasaran kegiatan pengabdian kepada masyarakat adalah para anggota kelompok wanita tani Sida Jodho Desa Depok Kecamatan Bawang Kabupaten Banjarnegara yang berjumlah sekitar 26 orang. Bentuk dan metode kegiatan yang dilakukan adalah kegiatan pendidikan masyarakat melalui penyuluhan, ceramah, dan diskusi langsung tentang pemanfaatan biofarmaka. Selain itu juga dilakukan kegiatan difusi ipteks melalui kegiatan pelatihan pemanfaatan tanaman biofarmaka dan kegiatan advokasi melalui pendampingan secara berkelanjutan. Metode ceramah dipilih untuk memberikan penjelasan atau materi mengenai khasiat tanaman obat atau biofarmaka. Setiap peserta diberikan hardcopy materi kegiatan. Adapun langkah-langkah kegiatan melalui tahapan persiapan dan pelaksanaan, tahap persiapan meliputi koordinasi dengan pihak desa lokasi pengabdian, penetapan waktu pelatihan; penentuan sasaran dan target peserta pelatihan, perencanaan materi pelatihan, pelaksanaan (Wulandari, 2018).

\section{HASIL DAN PEMBAHASAN}

Kegiatan pengabdian kepada masyarakat yang dilaksanakan di Desa Depok meliputi persiapan, pelaksanaan, dan evaluasi kegiatan. Kegiatan persiapan diawali dengan melakukan survei pendahuluan dan wawancara langsung dengan para anggota kelompok wanita tani Sida Jodho Desa Depok. Kegiatan tersebut dilakukan untuk mengetahui need assessmentdari masyarakat sehingga kegiatan efektif dan efisien sesuai dengan target yang dicapai. Berdasarkan hasil survei awal dan wawancara diperoleh informasi bahwa sebagian besar warga masyarakat yang tergabung dalam kelompok wanita tani belum memiliki pengetahuan mengenai cara pemanfaatan tanaman biofarmaka untuk pengobatan dan sebagai produk yang dapat diunggulkan berdasarkan potensi desa. Kegiatan dilaksanakan dalam bentuk penjelasan atau penyuluhan yang diawali dengan ceramah dan diskusi. Jumlah peserta yang hadir sebanyak 20 orang yang memiliki tingkat pendidikan berbeda-beda atau rata-rata pendidikan sekolah dasar. Secara jelas kegiatan yang dilakukan adalah memberikan penjelasan tentang pemanfaatan tanaman biofarmaka sebagai produk unggulan berbasis potensi desa dapat diuraikan sebagai berikut:

\section{a. Tanaman Biofarmaka Berbasis Potensi Desa Depok Bawang Banjarnegara}

Kegiatan utama pengembangan budidaya biofarmaka di masyarakat Desa Depok memanfaatkan lahan tegalan atau kering seluas 5 hektar dengan produktivitas mencapai 4,9 ton. Produksi atau hasil panen beserta harga jual tanaman biofarmaka yang dihasilkan oleh kelompok wanita tani Sida Jodho pada saat pendahuluan kegiatan secara jelas tertera pada Tabel 1. Jenis biofarmaka yang paling digemari atau banyak ditanam oleh para anggota kelompok adalah jenis jahe, kencur dan kunyit.

Tabel 1.Hasil Panen dan Harga Jual Produk Biofarmaka KWT Sida Jodho Desa Depok Kecamatan Bawang Per Hektar Tahun 2018

\begin{tabular}{clcc}
\hline No & Jenis Biofarmaka & Hasil Panen $(\mathrm{Kg})$ & Harga Jual/Kg $(\mathrm{Rp})$ \\
\hline 1 & Kencur & 1.000 & 25.000 \\
2 & Jahe & 2.000 & 6.000 \\
3 & Kapulaga & 100 & 40.000 \\
4 & Kunyit & 200 & 25.000 \\
5 & Lengkuas/Laos & 1.000 & 3.000 \\
6 & Sereh & 100 & 10.000 \\
7 & Mrica & 500 & 75.000 \\
\hline
\end{tabular}

Sumber : KWT Sida Jodho, 2018 
Sejak awal berdirinya kelompok wanita tani Sida Jodho belum sama sekali melakukan kegiatan pengolahan biofarmaka menjadi olahan produk lainnya. Hal ini disebabkan oleh keterbatasan pengetahuan dan keterampilan para anggota kelompok terhadap penanganan pascapanen dan pengolahan produk biofarmaka. Kebanyakan dari anggota kelompok menjual langsung hasil panen ke pedagang pengepul yang berasal dari luar Desa Depok dengan harga jual yang bervariasi setiap jenisnya. Berdasarkan Tabel 1, biofarmaka jenis mrica merupakan tanaman yang memiliki harga jual paling tinggi diantara yang lain, mencapai $\mathrm{Rp} 75.000,-/ \mathrm{Kg}$. Sementara harga jual biofarmaka paling rendah adalah jenis lengkuas atau laos mencapai $\mathrm{Rp} 3.000,-/ \mathrm{Kg}$ yang umumnya digunakan sebagai pelengkap bumbu dapur. Pada kegiatan tersebut masyarakat Desa Depok dapat mengetahui dan dapat melakukan identifikasi potensi dan pengembangan tanaman biofarmaka yang dikembangkannya.

\section{b. Pemanfaatan Biofarmaka Sebagai Produk Unggulan Masyarakat Desa Depok Banjarnegara}

Pada pelaksanaan kegiatan tersebut dilakukan difusi ipteks melalui pelatihan dan pemanfaatan tanaman biofarmaka yang dikembangkan oleh masyarakat Desa Depok Banjarnegara. Para anggota kelompok wanita tani Sida Jodho diberikan materi tentang pemanfaatan biofarmaka sebagai obat dan pelatihan tentang cara mengolah biofarmaka seperti jahe menjadi produk serbuk jahe atau dikenal sebagai jahe wangi yang siap dijual dan menjadi produk unggulan bagi masyarakat. Salah satu upaya yang saat ini gencar diwacanakan adalah pengembangan produk unggulan desa. Hal ini sebenarnya bukan sebuah barang baru, karena pada pemerintahan sebelumnya juga sudah di wacanakan konsep One Village One Product (OVOP) sebagai program pengembangan produk unggulan desa. Ada beberapa hal yang perlu di perhatikan sebelum sebuah desa menentukan produk unggulanya, yaitu; (1) produk unggulan desa hendaknya dapat di kembangkan oleh sebagian besar masyarakat. Tujuan utama untuk mensejahterakan masyarakat, (2) produk unggulan desa harus bisa di kembangkan secara masif dalam skala besar. Untuk bisa mengembangkan produk semacam ini, tentu kita harus memperhatikan ketersediaan bahan baku dan besarnya permintaan pasar, (3) produk unggulan desa dapat meningkatkan pendapatan masyarakat danpendapatan asli desa. Peningkatan pendapatan ini menjadi sangat penting untuk dijadikan pertimbangan. Sebuah produk unggulan yang bisa meningkatkan pendapatan masyarakat akan mengentaskan masyarakat dari jurang kemiskinan, bukan hanya menjadi sebuah kebanggaan semata (Anonim, 2017). Jenis dan manfaat tanaman biofarmaka yang paling banyak dikembangkan di Desa Depok Banjarnegara yang dapat dijadikan sebagai produk unggulan tersaji pada Tabel 2.

Tabel 2. Jenis dan Manfaat Tanaman Biofarmaka Desa Depok Banjarnegara

\begin{tabular}{|c|c|c|c|}
\hline No & Jenis & Manfaat/Kegunaan & Cara Menggunakan \\
\hline 1. & Kunyit & $\begin{array}{l}\text { Menghentikan pendarahan, obatgatal, } \\
\text { radang umbai usus buntu, radang rahim, } \\
\text { keputihan, obatsakit perut dan gangguan } \\
\text { liver }\end{array}$ & $\begin{array}{l}\text { Rimpang Kunyit diparut ditambah } \\
\text { airmatang, diperas, airnya diminum, } \\
\text { rimpang dibuat tepung disedu dengan air } \\
\text { panas ditambah madu }\end{array}$ \\
\hline 2. & Kencur & $\begin{array}{l}\text { Secara empiris digunakan } \\
\text { untuk : batuk, infeksi bacteri, disentri, } \\
\text { selera makan, tonikum, masuk angin, } \\
\text { sakit perut, obat } \\
\text { asma dan anti jamur }\end{array}$ & $\begin{array}{l}\text { Rimpang digunakan secara langsung, } \\
\text { ataudi olah seperti tepung, ddicampur air } \\
\text { dandapat ditambah gula untuk diminum } \\
\text { airnya }\end{array}$ \\
\hline 3. & Jahe & $\begin{array}{l}\text { Sebagai obat tradisional dan } \\
\text { fitofarmaka karena adanya } \\
\text { gigerolnya, mengatasi nyeri padatulang } \\
\text { ( adanya bahan aktif dari ekstrak) }\end{array}$ & $\begin{array}{l}\text { Rimpangnya di olah sebagai } \\
\text { ekstrakmaupun tepung dan digunakan } \\
\text { secaralangsung }\end{array}$ \\
\hline 4. & Lengkuas & $\begin{array}{l}\text { Eksim, panu,gabag, koreng, } \\
\text { radang lambung dan radang anaktelinga }\end{array}$ & $\begin{array}{l}\text { Rimpang lengkuas diparut langsung } \\
\text { disedudengan air panas, dinginkan } \\
\text { airnya diminum atau rimpang diiris-iris } \\
\text { direndam dalam air dimasukkan } \\
\text { dalamstoples lalu dijemur di bawah } \\
\text { sinar matahari, airnya dapat disimpan }\end{array}$ \\
\hline
\end{tabular}


5. Kapulaga Sebagai penguat rasa pada makanan, mengatasi mulas,kejang usus, keluhan hati dan kantong empedu, kehilangan selera makan, kedinginan, batuk, sakit mulut dan tenggorokan, penyakit infeksi, stimulan untuk masalah kencing,sembelit

6. Sereh

7. Mrica dandiminum saat diperlukan.

Berbagai bentuk sedian untuk suplemen atau ekstrak kapulaga adalah sebagai cairan, bubuk, biji (kering dan utuh), teh

Sebagai bumbu dapur untuk mengharumkan makanan. Minyak serai adalah minyak atsiri yang diperoleh dengan jalan menyuling bagian atas tumbuhan tersebut.

Ambil 1/2 sendok teh lada/merica dan kopi, lalu seduh dengan air panas. Lalu dapat langsung diminum sebelum rasa sakit mulai datang. Dapat juga ditambahkan dan diramu dengan mencampur daun pepaya, yaitu tangkainya, sepotong temu ireng, seperempat daun tarum dan garam. Cara Meramunya sangat mudah dengan menghaluskan semua bahan lalu ditambah setengah gelas air, peras lalu saring dan siap diminum 2-3 kali sehari.

Sumber: Syarif, dkk, 2015

Melalui kegiatan penyuluhan dan pelatihan tersebut para anggota kelompok wanita tani menjadi paham dan terampil dalam memanfaatkan tanaman biofarmaka sebagai obat tradisional atau obat herbal karena memiliki efek samping yang relative sedikit dibandingkan dengan obat kimia modern. Hal tersebut senada dengan kajian yang dikemukakan oleh Sari (2006) bahwa penggunaan obat tradisional secara umum dinilai lebih aman dari pada penggunaan obat modern. Hal ini disebabkan karena obat tradisional memiliki efek samping yang relatif lebih sedikit dari pada obat modern. Efek samping obat tradisional relatif kecil jika digunakan secara tepat, yang meliputi sebagai berikut:

a. Kebenaran bahan.Tanaman obat di Indonesiaterdiri dari beragam spesies yangkadang kala sulit untuk dibedakansatu dengan yang lain. Kebenaranbahan menentukan tercapai atautidaknya efek terapi yang diinginkan.

b. Ketepatan dosis. Tanaman obat, seperti halnya obat buatan pabrik memang tak biasa dikonsumsi sembarangan. Tetap adadosis yang harus dipatuhi, seperti halnya resep dokter

c. Ketepatan waktu penggunaan. Kunyit diketahui bermanfaa tuntuk mengurangi nyeri haid dan sudah turun-temurun dikonsumsi dalam ramuan jamu kunir asam yang sangat baik dikonsumsi saat datang bulan.

d. Ketepatan cara penggunaan. Satu tanaman obat dapat memiliki banyak zat aktif yang berkhasiat di dalamnya. Masing-masing zat berkhasiat kemungkinan membutuhkan perlakuan yang berbeda dalam penggunaannya.

e. Ketepatan telaah informasi.Perkembangan teknologi informasisaat ini mendorong derasnyaarus informasi yang mudah untukdiakses. Informasi yang tidak didukung oleh pengetahuan dasar yang memadai dan telaah atau kajian yangcukup seringkali mendatangkan halyang menyesatkan. Ketidaktahuan bisa menyebabkan obat tradisional berbalik menjadi bahan membahayakan.

f. Tanpa penyalahgunaan $t$ anaman obat maupun obat tradisional relatif mudah untuk didapatkan karena tidak memerlukan resep dokter, hal ini mendorong terjadinya penyalahgunaan manfaat dari tanaman obat maupun obat tradisional tersebut. 
g. Ketepatan pemilihan obat untuk indikasi tertentu. Dalam satu jenis tanaman dapat ditemukan beberapa zat aktif yang berkhasiat dalam terapi. Rasio antara keberhasilan terapi dan efek samping yang timbul harus menjadi pertimbangan dalam pemilihan jenis tanaman obat yang akan digunakan dalam terapi.

Semangat dan motivasi yang tinggi dari para peserta menumbuhkan produktivitas kegiatan. Hal tersebut didukung dengan banyaknya pastisipasi peserta yang hadir pada kegiatan hampir 76 $\%$. Sebagai kegiatan akhir yaitu evaluasi, maka kegiatan perlu diteruskan dalam bentuk pendampingan secara berkelanjutan untuk memastikan bahwa apa yang telah diberikan dan dilatih benar-benar sesuai dengan target yang diharapkan. Secara umum para anggota kelompok wanita tani Desa Depok telah memahami pemanfaatan tanaman biofarmaka sebagai produk unggulan yang dapat meningkatkan pendapatan dan kesejahteraan. Oleh karena itu disepakati bahwa kegiatan pengabdian ini bermanfaat dan bermakna karena penting untuk meningkatkan pengetahuan mereka tentang pemanfaatan tanaman tanaman obat (biofarmaka) bagi kesehatan dan tentu saja sebagai produk unggulan dapat menghasilkan keuntungan.

\section{KESIMPULAN}

Berdasarkan pada hasil kegiatan maka dapat disimpulkan bahwa kegiatan pengabdian kepada masyarakat yang dilakukan dikatakan berhasil meskipun belum optimal. Maka dari itu secara umum output yang dihasilkan adalah (a) meningkatnya pengetahuan dan pemahaman para anggota kelompok wanita tani Desa Depok Banjarnegara tentang pentingnya pemanfaatan tanaman biofarmaka bagi kesehatan, (b) meningkatnya keterampilan para anggota kelompok wanita tani dalam mengolah, meracik, memanfaatkan dan cara menggunakan setiap jenis tanaman biofarmaka yang dikembangkan, (c) secara tidak langsung membawa dampak perubahan pada peningkatan pendapatan keluarga dari hasil pemanfaatan tanaman biofarmaka sebagai produk unggulan berbasis potensi desa.

\section{DAFTAR PUSTAKA}

Anonim, 2012.Pengertian Tanaman Obat, Jenis dan Pemanfaatannya. http://pengertian tanaman obat. blogspot.com/2012/10/pengertian-tanaman-obat-jenis-dan.html. Diakses Senin 1 Oktober 2018.

Anonim, 2017. Menggagas Pengembangan Produk Unggulan Desa. http://menggagaspengembangan-produk-unggulan-desa.wonogondo.kabpacitan./2017.Diakses Senin 1 Oktober 2018.

Kelompok Wanita Tani Sida Jodho. 2018. Profil KWT Sida Jodho. Desa Depok. Banjarnegara Lestaridewi, Ni Ketut dkk, 2017. Kajian Pemanfaatan Tanaman Sebagai Obat Tradisional di Desa Tolai Kecamatan Torue Kabupaten Parigi Moutong. Jurnal e-JIPBIOL. Universitas Tadulako. Vol.5 (2): 92-108, Desember 2017

Pemerintah Kecamatan Bawang. 2018. Kecamatan Bawang Dalam Angka, 2018.

Sari, Lusia Oktora RK, 2006. Pemanfaatan Obat Tradisional dengan Pertimbangan Manfaat dan Keamanannya. Review Ilmiah.Majalah Ilmu Kefarmasian, Vol. III, No.1, April 2006, Universitas Jember.

Syarif, Pudjiati dkk, 2015. Diskripsi dan Manfaat Tanaman Obat di PedesaanSebagai Upaya Pemberdayaan Apotik Hidup(Studi Kasus di Kecamatan Wonokerto). Jurnal Penelitian. Fakultas Pertanian. Universitas Pekalongan.

Tukiman, 2014.Pemanfaatan Tanaman Obat Keluarga (Toga) Untuk Kesehatan Keluarga. Bagian Pendidikan Kesehatan dan Ilmu Perilaku Fakultas Kesehatan Masyarakat. Universitas Sumatera Utara.

Wulandari, Ririn L, 2018.Pemanfaatan Tanaman Obat Keluarga (Toga) Untuk PengobatanDiabetes Melitus. Jurnal Abdimas.Universitas Wahid Hasyim, Semarang. Vol. 3 No. 1, April 2018. 